\title{
BISERICILE BAROC ALE CONTRAREFORMEI LA ȘVABII SĂTMĂRENI ${ }^{1}$
}

cercetător dr. arh. Maria Bostenaru Dan

Universitatea de Arhitectură și Urbanism „Ion Mincu”, București

Maria.Bostenaru-Dan@alumni.uni-karlsruhe.de

\section{Rezumat}

După reforma bisericii introdusă de Luther și Calvin, biserica catolică a lansat un program larg așa numita ContraReformă. Una din expresiile Contra-Reformei a fost construcția de biserici în stil baroc. Bisericile baroc, cu spațiul lor dinamic și bogat ornamentat, trebuiau să transpună în arhitectură ideile teologice ale bisericii. Primele biserici baroc au fost construite la Roma, precum în cazul altor stiluri arhitecturale.

De asemenea, în perioada Contra-Reformei, a avut loc un larg proces de coloniarizare al monarhiei Habsburgice, pentru a mări numărul populației catolic. În acest context în zona Satu-Mare contele de Károlyi din Carei a adus șvabi (numiți ulterior șvabi dunăreni pentru că au călătorit pe Dunăre cu așa numita Ulmer Schachtel) din zona Oberschwaben (Suabia superioară) din Germania. Regiunea Oberschwaben este caracterizată de prezența a numeroase mănăstiri de care aparțineau coloniștii. Pe durata emigrării au fost construite și aici biserici baroc, prin școala Voralberg, o școală de arhitectură austriacă, compusă din familii de arhitecți. Și în județul Satu-Mare sub mecenatul familiei de Károlyi au fost construite biserici baroc, de exemplu la Carei sau în satele înconjurătoare, ultimele opere ale lui Josef Bittheuser. Am desfășurat două călătorii de studii, în Oberschwaben și respectiv în Satu-Mare, pentru a investiga acest patrimoniu arhitectural condiționat de contextul istoric al contra-reformei. Am întocmit hărți care suprapun patrimoniul baroc, astăzi un circuit cultural, cu zonele de emigrare. Bisericile din Satu-Mare diferă de cele din Oberschwaben fiind mai simple și mai apropiate de cele din Banat, unde au venit următorii coloniști, aduși de împărăteasa Maria Theresia. Din acest motiv a fost studiată și relația cu Viena. O diferență importantă este și cea dintre biserică și mănăstire, în Oberschwaben numeroase biserici fiind biserici mănăstirești, cu bibliotecă baroc. În Oberschwaben mănăstirile au fost secularizate pe vremea lui Napoleon.

Cuvinte cheie: migrație, Baroc, biserică

\footnotetext{
${ }^{1}$ Mulţumiri: Cercetarea prezentată a fost realizată în cadrul unui proiect finanțat de Academia Maghiară de Științe prin bursa DOMUS în țara de origine cu titlul „Imigrarea șvabilor în secolul al XVIII-lea în județul Satu-Mare interferențe și provocări în arhitectura ecleziastică și rurală" https://sites.google.com/view/domusszulofoldiosztondij/home
} 


\section{Introducere}

Scopul acestei cercetări a fost să compare arhitectura baroc a bisericilor precum și arhitectura vernaculară din Oberschwaben (Suabia superioară) din Germania, de unde coloniștii au început să vină în 1712 spre județul Satu-Mare de azi din România de SV, împrejurul sediului conților de Károlyi din Carei, care i-au adus, și cea din Satu-Mare. Este înscrisă într-o temă mai largă care privește deci nu numai arhitectura ecleziastică, ci și pe cea vernaculară. Unul din motive a fost investigarea modificărilor dintr-o zonă seismică, întrucât multe din aceste biserici au fost afectate de cutremurul din 1834 din Érmellék.

Unul din obiective era documentarea faptului în ce măsură emigrarea a avut loc din situri care mai târziu au înflorit în perioada baroc, când a avut loc emigrarea, prin noi construcții, sau dacă emigrarea a fost dictată de motive economice către straturile mai sărace ale societății. Un alt obiectiv a fost stabilirea factului dacă prin migrare migranții au adus cu ei modele din țara de baștină sau s-au adaptat la condițiile locale unde s-au așezat.

La puțin timp după pacea de la Satu-Mare (1711) regiunea din jurul orașului Carei era deșertificată de război și contele a vrut să aducă o nouă forță, în special întrucât pământul era bogat și aducea recoltă bună. Geografia locurilor de emigrare din Oberschwaben era diferită era o regiune deluroasă de livezi în vreme ce în Carei este câmpie cu agricultură de grâu și de porumb. Totuși, chemarea a fost de succes, și pe parcursul unui secol numeroase noi sate au fost înființate. Diferit de alte regiuni din Românie de unde etnicii germani au emigrat înapoi în Germania pe parcursul trecutului recent, în Satu-Mare multe localități mai prezintă mari părți din populația originară, motiv pentru care această cercetare este interesantă. S-a scris puțin despre arhitectura din Satu-Mare. Julia Bara a scris o teză de doctorat (Bara, 2013) și numeroase articole, dar încă se mai așteaptă o monografie. Cercetarea privind șvabii sătmăreni se axează mai ales pe punctul de vedere al antropologiei (Roșu, 2015). Având rude în zonă, acest aspect a putut fi văzut și din interior. Situația este diferită în Oberschwaben. Unele din bisericile baroc din Oberschwaben sunt relevante pentru istoria arhitecturii mondiale (VoitecDordea, 1994, Fletscher, 1975).

Metoda principală de cercetare a fost cercetarea pe teren. Au fost realizate două călătorii de studiu, una în Oberschwaben și una în Satu-Mare. Pe parcursul acestora a fost colectat material fotografic ca sursă primară. Dacă datorită faptului că este o rută culturală bisericile din Oberschwaben sunt bine documentate, în Satu-Mare ele sunt greu accesibile și nu sunt documentate suficient în starea lor de acum.

În pregătirea pentru călătoriile de studiu au fost desenate diferite hărți. În acest scop a fost folosită cartea lui Stefan Vonház (1987), un material foarte util, care cuprinde locurile de origine și de așezare ale migranților. Aceasta a fost suprapusă peste ruta culturală și hărțile seismice printre altele. Au fost realizate story maps ale rezultatelor vizuale. Până acum a fost realizată puțină cercetare de arhivă, și aceasta este o limitare.

Inovația principală este documentarea unui patrimoniu momentan insuficient documentat și hărțile inovative care permit să se vadă care sunt cele mai relevante locuri din cercetări spațiale și a relațiilor dintre spatii cu dimensiuni, roluri și semnificații diferite, în interiorul unui ansamblu arhitectural coerent. 


\section{Metodologie}

Întrebările de cercetare au fost abordate cu metoda cartării. Utilizând înregistrările istorice colectate de Stefan Vonház (1987) locurile de unde au venit coloniștii au fost cartate și comparate cu cele atinse de elanul constructive pentru biserici baroc în cadrul ContraReformei menționate.

Suabia superioară prezintă un număr larg de biserici baroc în mănăstirile ei, care formează o rută culturală, Strada Barocului Suabiei de Sus (din 1966) (Oberschwäbische Barockstraße 2019a și b). În contextul bibliografiei internaționale privind lucrările baroc relevante (VoitecDordea, 1994, Hostiuc, 2010, Fletcher, 1975) și luând în considerare analiza hărților cu instrumente specifice, au fost stabilite localitățile principale de vizitat în cadrul călătoriei de studiu și patrimoniul documentat.

Dacă bisericile baroc din Suabia Superioară sunt bine documentate, cele din Satu-Mare nu sunt. Există puține referințe în bibliografie sau internet despre ele, așa că vizita personală a ajutat foarte mult cercetarea. Am avut comunicare personal și cu Júlia Bara care a obținut doctoratul cercetând această temă (Bara, 2013). Anterior am desfășurat cercetare privind arhitectura din Carei în cadrul unei burse postdoctorale (Bostenaru, 2018). Muzeul șvabilor dunăreni din UIm a fost vizitat recent în cadrul unei alte deplasări pe teren. Călătoria la Viena pentru a prezenta rezultatele a fost utilă pentru a încadra cercetarea în contextul arhitecturii austriece, care a putut influența cercetarea la fel de mult ca locurile de origine.

Deși construcția de biserici a fost relevantă întrucât Contra-Reforma bisericii a fost motivul imigrării, cercetarea a avut în vedere și arhitectura vernaculară. În acest mod m-am apropiat de Kevin Lynch (1960) analiza de tipul „imaginea orașului”, întrucât am luat în considerare atât reperele, cât și clădirile obișnuite. Dacă reconstrucția după avarii se leagă de cutremurul din 1834, avariile la clădirile de arhitectură vernaculară sunt cele pe baza cărora s-a stabilit magnitudinile în studiile lui Zsíros (1983). Toate hărțile sunt libere de accesat de pe pagina proiectului (https://sites.google.com/view/domusszulofoldiosztondij/ ).

Emit și ipoteza conform căreia activitatea puternică de construcție de biserici din Germania la sfârșitul războiului de 30 de ani nu a avut popularitate în rândul țăranilor, prin paralelism cu cele relatate în romanul privind construcția mănăstirii Mafra de Jose Saramago.

Cu scopul de a realiza un instrument de vizualizare a migrației din Oberschwaben în Satu-Mare autoarea a participat la un workshop Urban Eye în București participând la elaborarea unui joc privind cum poate ceva fizic să fie transportat în cadrul migrației.

\section{Rezultate și discuție}

Atât arhitectura ecleziastică precum și cea vernaculară sunt diferite în locurile de origine și în cele de colonizare. Interioarele bisericilor (despre care am scris în Bostenaru, 2019a) sunt pictate bogat în locurile de origine, ceea ce nu este cazul în Satu-Mare.

Fig. 1 și Tabelul 1 sumarizează efectele cutremurului. 


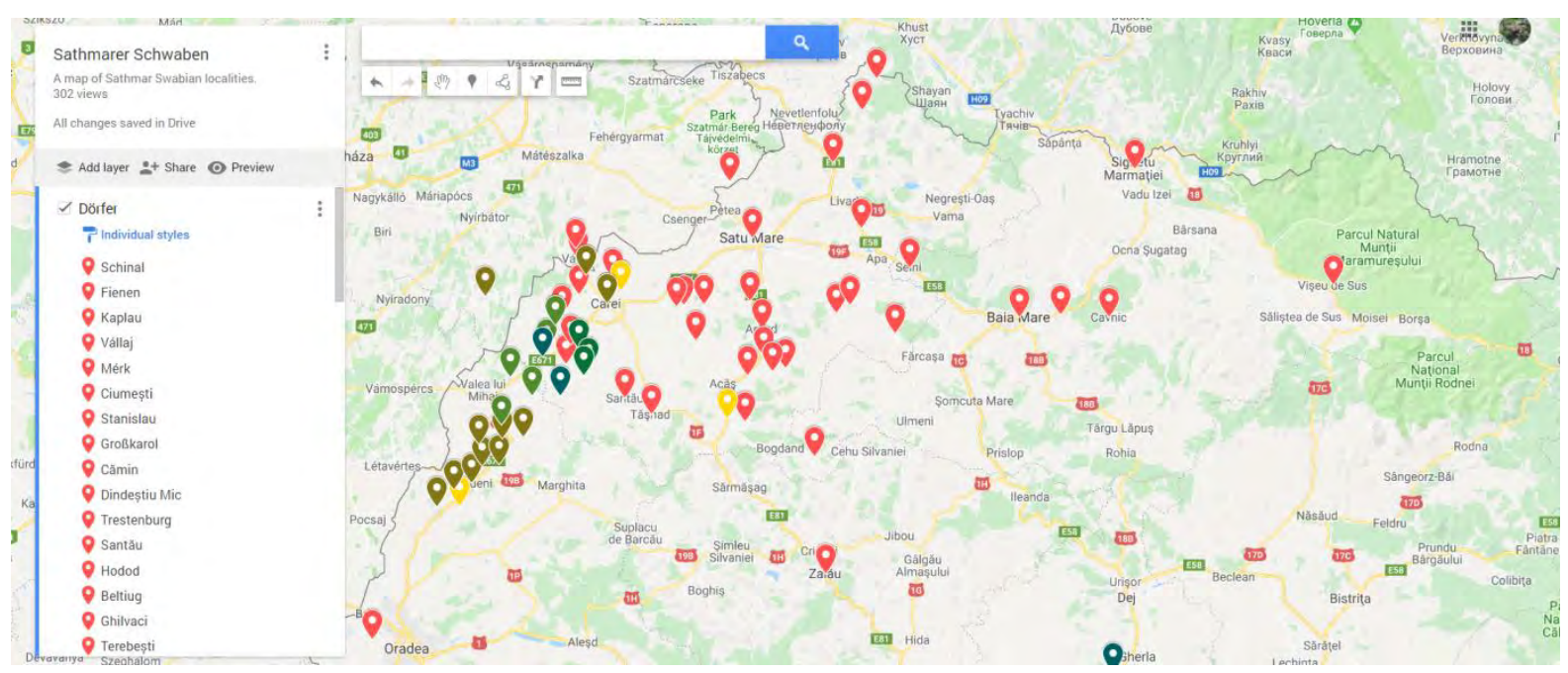

Fig. 1. Localități ale șvabilor sătmăreni suprapuse peste intensitățile cutremurului din 1834 (după Zsíros, 1983). Sursa: Vezi harta interactivă la https://drive.google.com/open?id=1VojsRwIB1L94UsoziNgTxyQMVG-bzVuH\&usp=sharing Vezi și INFP (2019).

Tabel 1. Avariile suferite de biserici în cutremurul din 1834 din Érmellék

\begin{tabular}{|c|c|}
\hline Biserica & Efectele cutremurului din 1834 \\
\hline $\begin{array}{l}\text { Biserica reformată } \\
\text { Ciumești }\end{array}$ & 1841 înlocuirea inelului (Fig. 2) \\
\hline $\begin{array}{l}\text { Biserica romano- } \\
\text { catolică Ciumești }\end{array}$ & $\begin{array}{l}\text { Prima mică biserică din } 1815 \text { a suferit avarii și s-a luat decizia reconstrucției } \\
\text { (Fig. 2) }\end{array}$ \\
\hline $\begin{array}{l}\text { Biserica romano- } \\
\text { catolică Sf. Iosif din } \\
\text { Calasanz din Carei }\end{array}$ & $\begin{array}{l}\text { Prăbușirea turnului, reconstrucție a lui Miklos Ybl cu un turn de înălțime } \\
\text { redusă. (Fig. 3) }\end{array}$ \\
\hline Biserica din Căpleni & Construită în cadrul reconstrucției după cutremur (Fig. 4) \\
\hline $\begin{array}{l}\text { Biserica reformată } \\
\text { church Carei }\end{array}$ & $\begin{array}{l}\text { Turnul s-a înclinat, acoperișul și clopotul s-au prăbușit. Pe } 26 \text { iunie } 1836 \text { a fost } \\
\text { un incendiu care a avariat acoperișul. Turnul a fost reparat în } 1877 \text { și prevăzut } \\
\text { cu un acoperiș nou din metal. (Bara, 2016) (Fig. 3) }\end{array}$ \\
\hline $\begin{array}{l}\text { Biserica din } \\
\text { Moftinu Mare }\end{array}$ & Nu a suferit avarii semnificative (Fig. 3) \\
\hline Biserica din Șandra & $\begin{array}{l}\text { În cadrul reparațiilor după cutremurul din } 1834 \text { tavanul a devenit plat cu } \\
\text { excepția sacristiei și a balconului de sub orgă. (Bara, 2016) - fotografie de } \\
\text { arhivă la https://maps.hungaricana.hu/en/MOLTervtar/8215/ }\end{array}$ \\
\hline Biserica din Petrești & $\begin{array}{l}\text { Avariată, turnul s-a prăbușit peste nava principală. În consecință bolțile au fost } \\
\text { schimbate cu un tavan plat în interior, bolțile originale rămânând numai în } \\
\text { sacristie. În } 1861 \text { turnul a fost reconstruit (Bara, 2016). (Fig. 6) }\end{array}$ \\
\hline Biserica din Foieni & $\begin{array}{l}\text { Avariată, turnul s-a înclinat și acoperișul turnului a fost avariat, reparat în } 1838 \\
\text { (Bara, 2016). (Fig. 7) }\end{array}$ \\
\hline $\begin{array}{l}\text { Biserica greco- } \\
\text { catolică din Carei }\end{array}$ & Puternic avariată dar reparată. Noi reparații în 1888. (Fig. 5) \\
\hline
\end{tabular}


Arhitecții din Oberschwaben erau austrieci, în vreme ce pentru Banat, unde colonizarea a fost organizată de Maria Tereza, au existat planuri tipizate de la Viena, deși sunt controverse în cercetare privind influența locurilor de origine și aici. Pentru Satu-Mare arhitectul bisericii catolice Sf. Iosif din Calasanz precum și planurile inițiale ale bisericii din Foieni (Bara, 2016) au venit de la Viena (Bara, 2011) (Fig. 8), dar celelalte, mai numeroase, din Würzburg (Bara, 2016), aproape de arhitectul șvab care a construit Mafra în Portugalia. Turnul bisericii Sf. Iosif din Calasanz a fost distrus de cutremur, dar putem vedea turnuri ale arhitectului la biserica Serviten din Viena, întrucât celălalt turn de la Viena a fost de asemenea distrus (Fig. 8). Josef Bittheuser, arhitectul din Würzburg, trebuie să fi văzut lucrări ale lui Balthasar Neumann (Fig. 9) când s-a format în orașul lui de baștină (Bostenaru, 2019b). Aceasta crează un link la barocul sud-german, atât cel din regiunea Oberschwaben, cât și cel din Würzburg si Bruchsal, din care unele clădiri sunt acum administrate de Staatliche Schlösser und Gärten Baden-Württemberg sau de Bayrische Verwaltung der Staatlichen Schlösser, Gärten und Seen.

\section{Concluzii}

În această lucrare am cartat aspecte relevante ale imigrării șvabilor din Oberschwaben în SatuMare, inițiate sub contele Sándor Károlyi în 1712. Imigrarea a fost o consecință a păcii din SatuMare (1711), când familia nobiliară a devenit de conte din baron. În același timp Maria Tereza a susținut aducerea coloniștilor, care erau catolici, către zonele deșertificate de război, în cadrul Contra-Reformei. Coloniștii Mariei Tereza au venit mai târziu. În consecință familia contelui s-a extins în toată Ungaria. Multe din castelele familiei au fost construite de Miklos Ybl care a devenit arhitectul familiei după ce a contribuit când era tânăr la reconstrucția de după cutremurul din 1834.
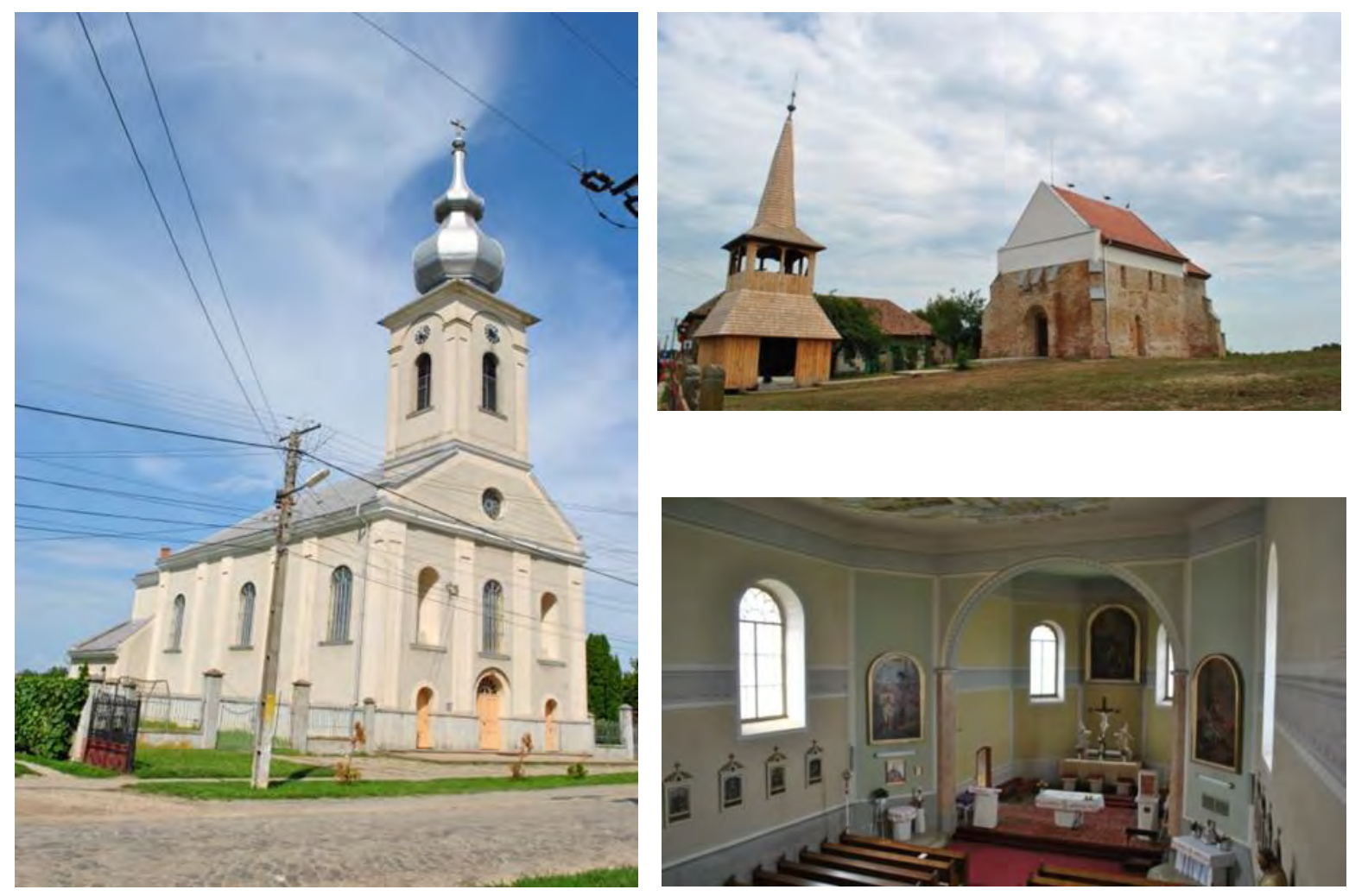

Fig. 2. Biserica romano-catolică din Ciumești (1854-1856). Arhitect: Albin Tischler. Sus dreapta: biserica reformată din Ciumești 

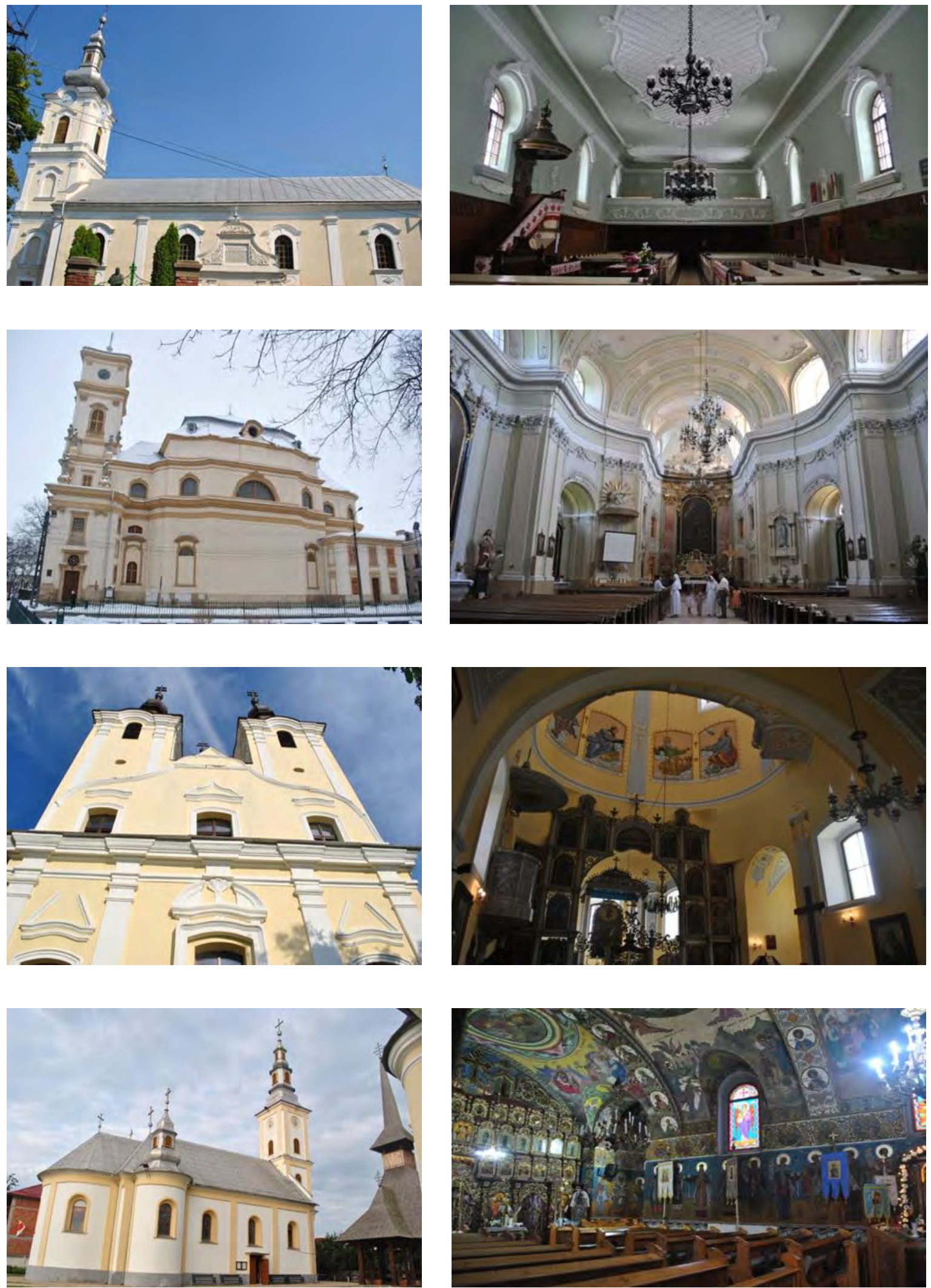

Fig. 3. Bisericile din Carei: biserica reformată, extinsă 1746 - 1752 de arhitectul Josef Bittheuser (sus), biserica romano-catolică Sf. losif din Calasanz, arhitect Franz Sebastian Rosenstingl (1769-1779) (mijloc sus), biserica Greco-catolică (1737-1739) (mijloc jos) și biserica ortodoxă (1752-) (jos) 

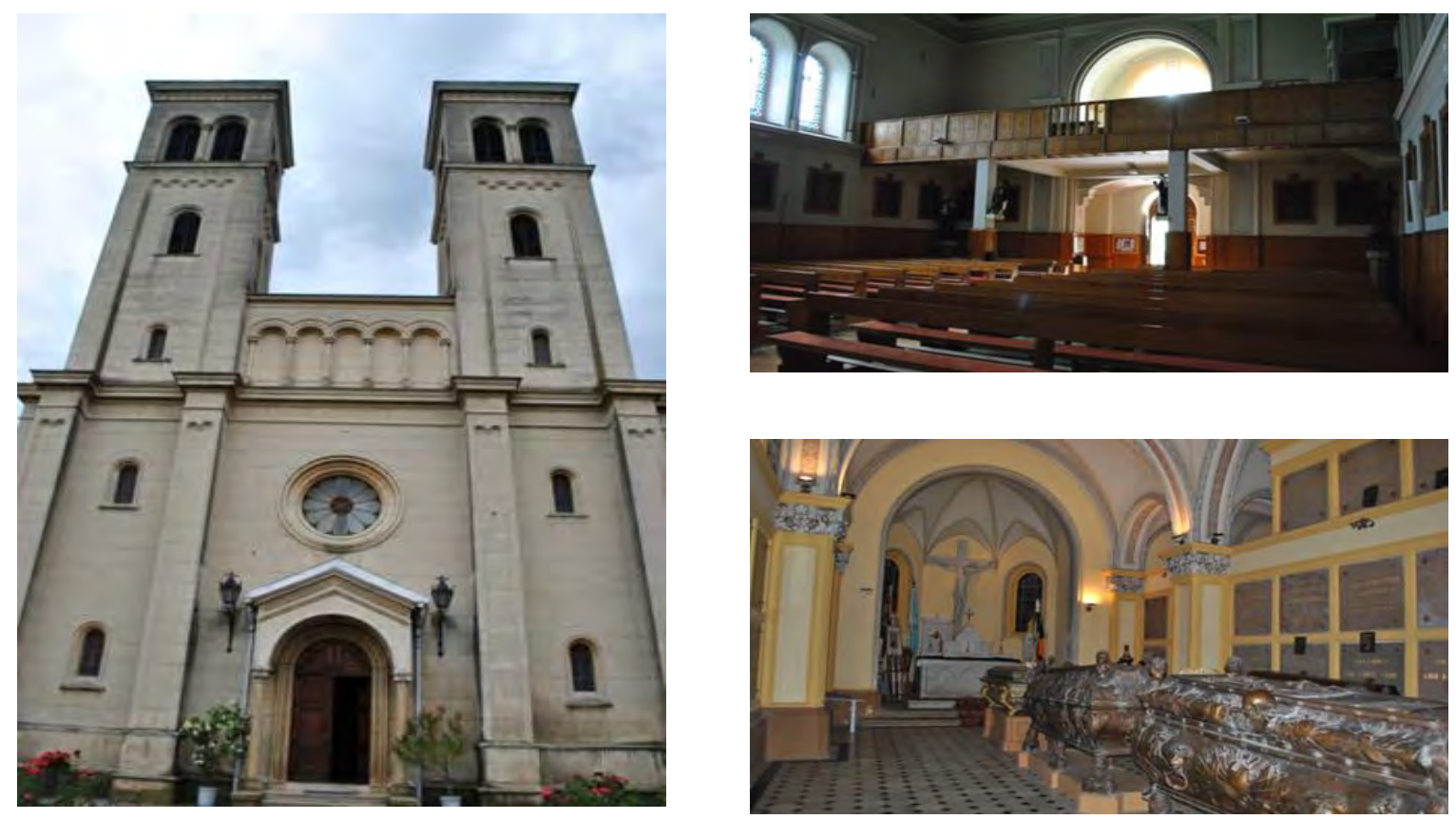

Fig. 4. Biserica din Căpleni (1842-1848), arhitect Miklos Ybl
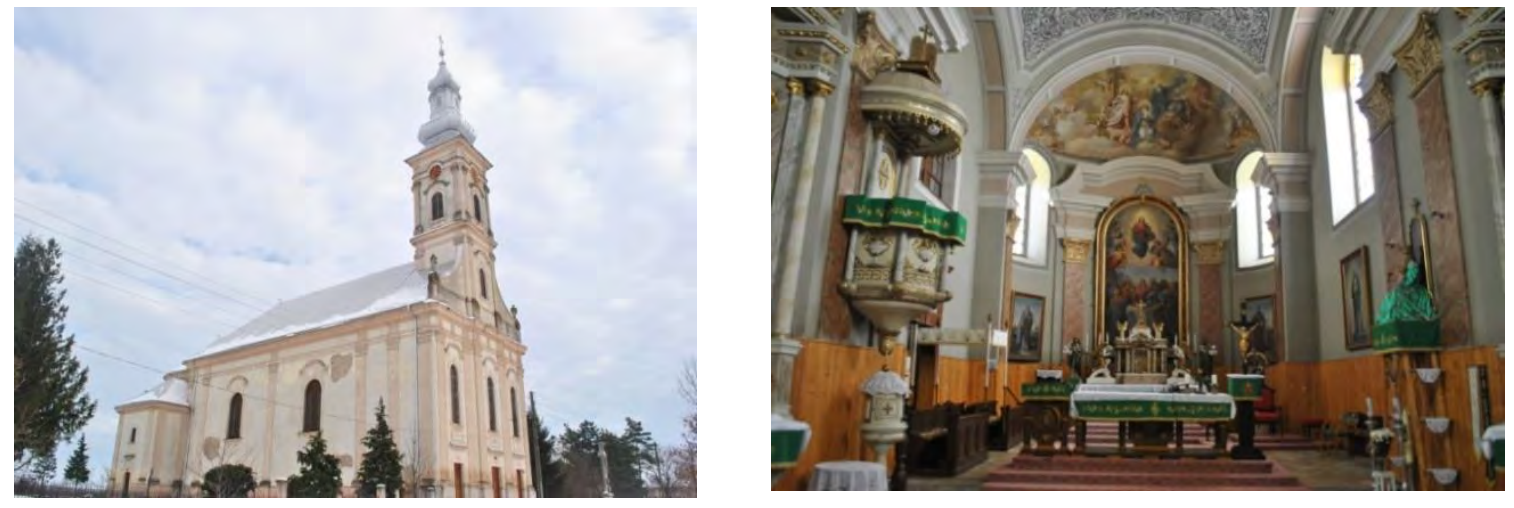

Fig. 5. Biserica din Moftinu Mare (1793-1797), arhitect Josef Bittheuser
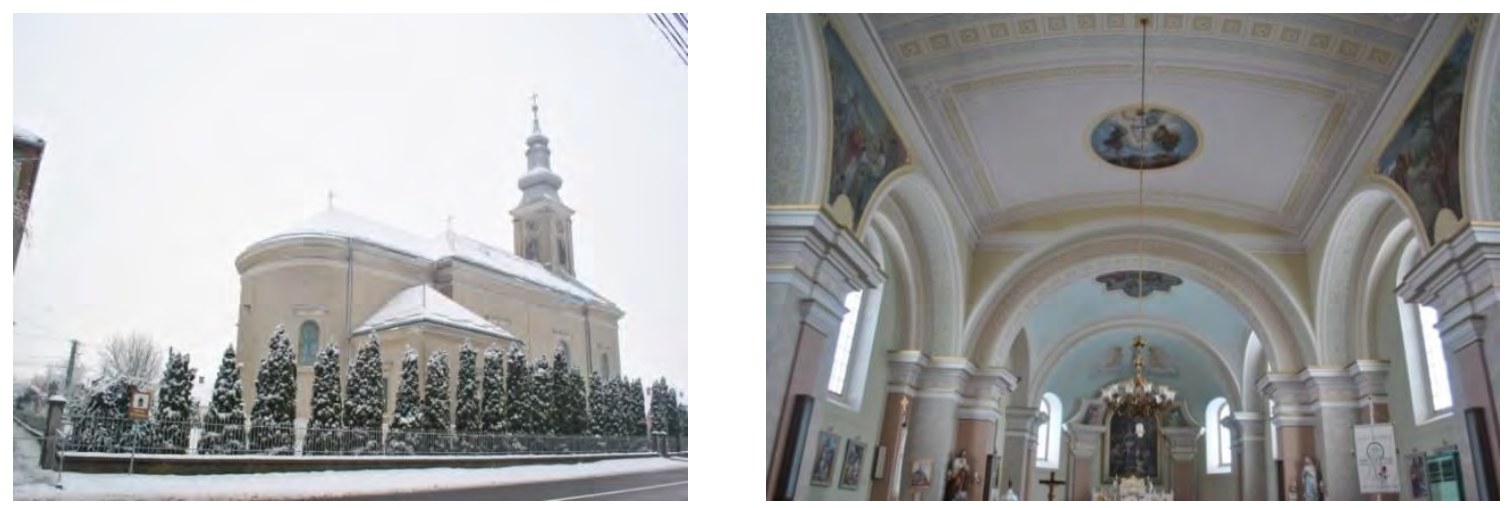

Fig. 6. Biserica din Petrești (1784-1786), arhitect Josef Bittheuser 

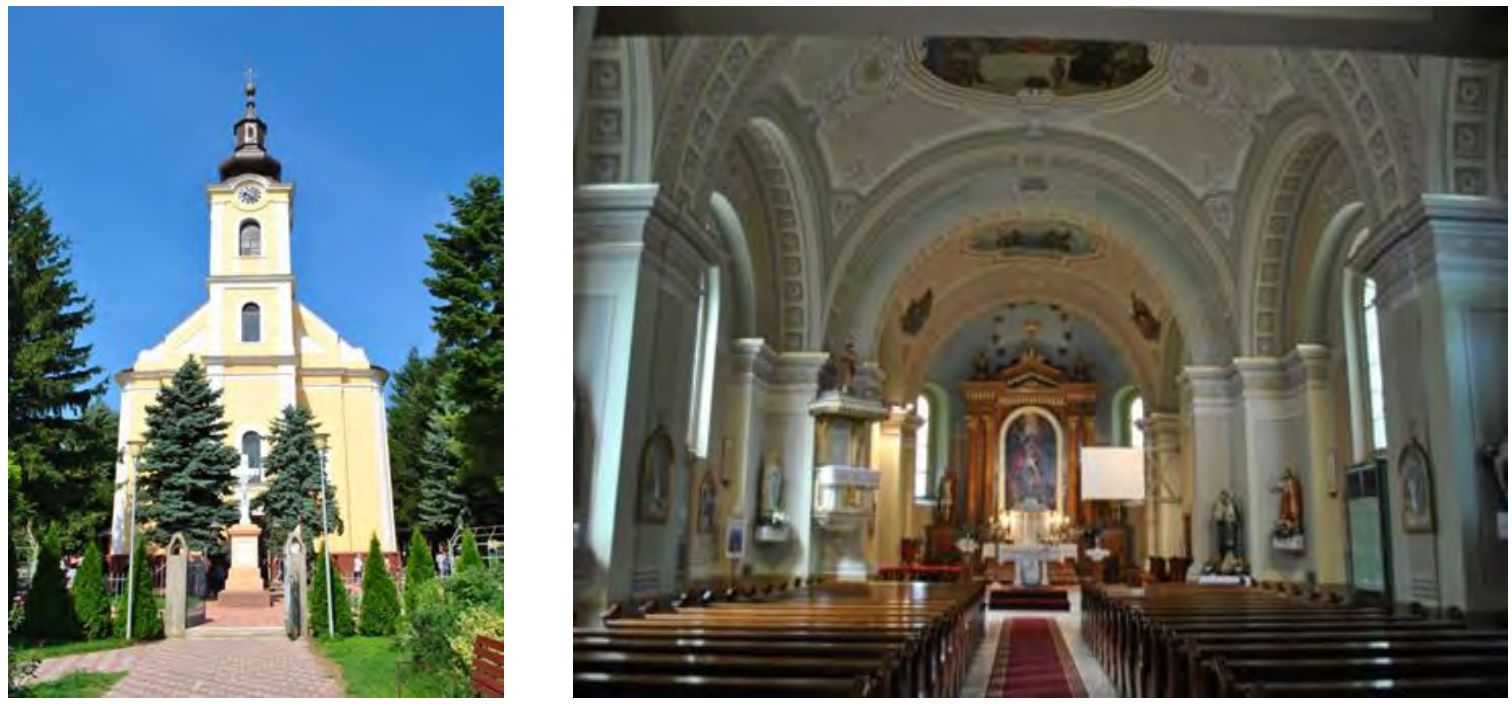

Fig. 7. Biserica din Foieni (1783-1785), arhitect Josef Bittheuser
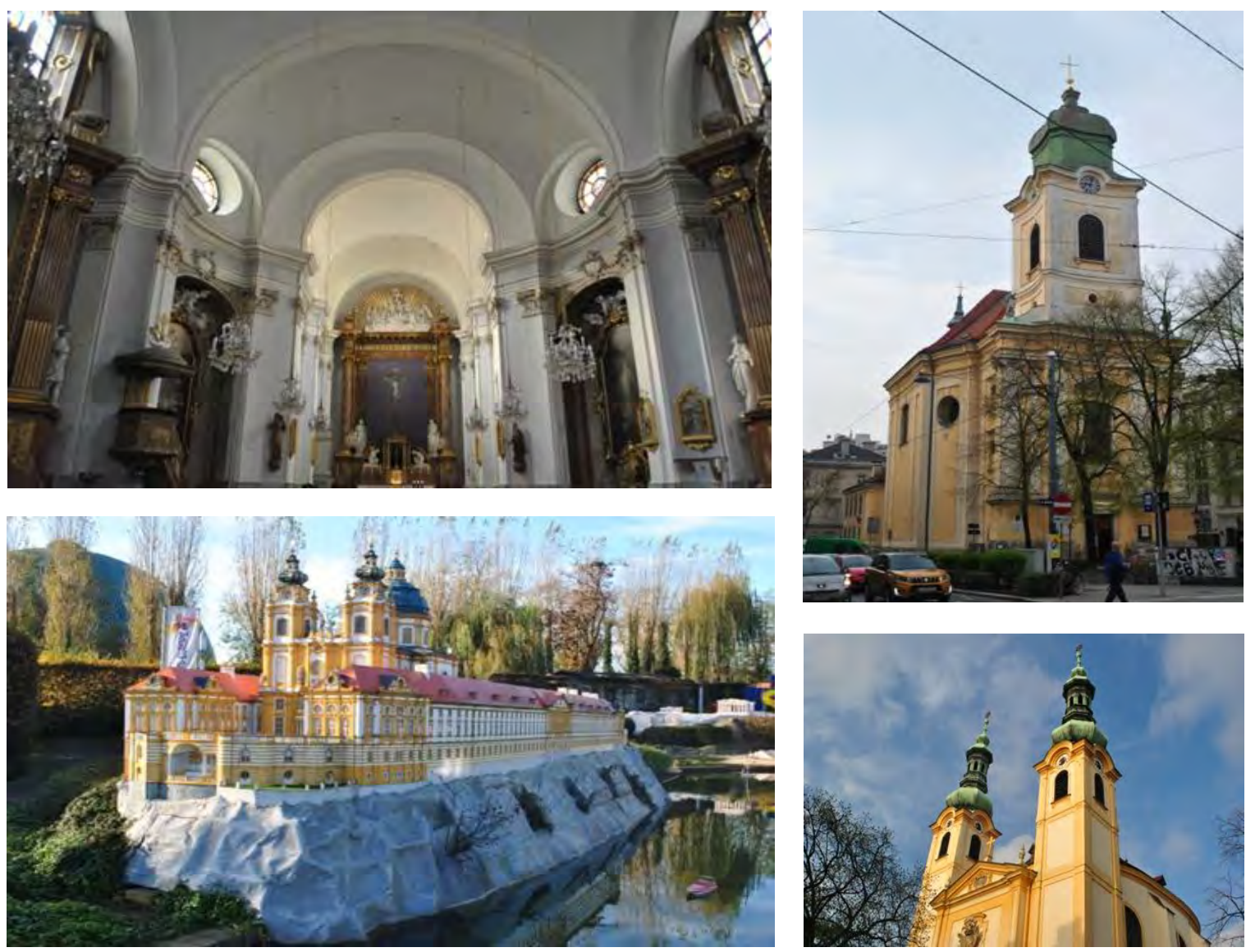

Fig. 8. Biserica din (sus) și biserica Serviten (jos stânga), Viena, arhitect Franz Sebastian Rosenstigl. Macheta mănăstirii Melk la Minieurope în Bruxelles (jos dreapta), unde a lucrat arhitectul. 

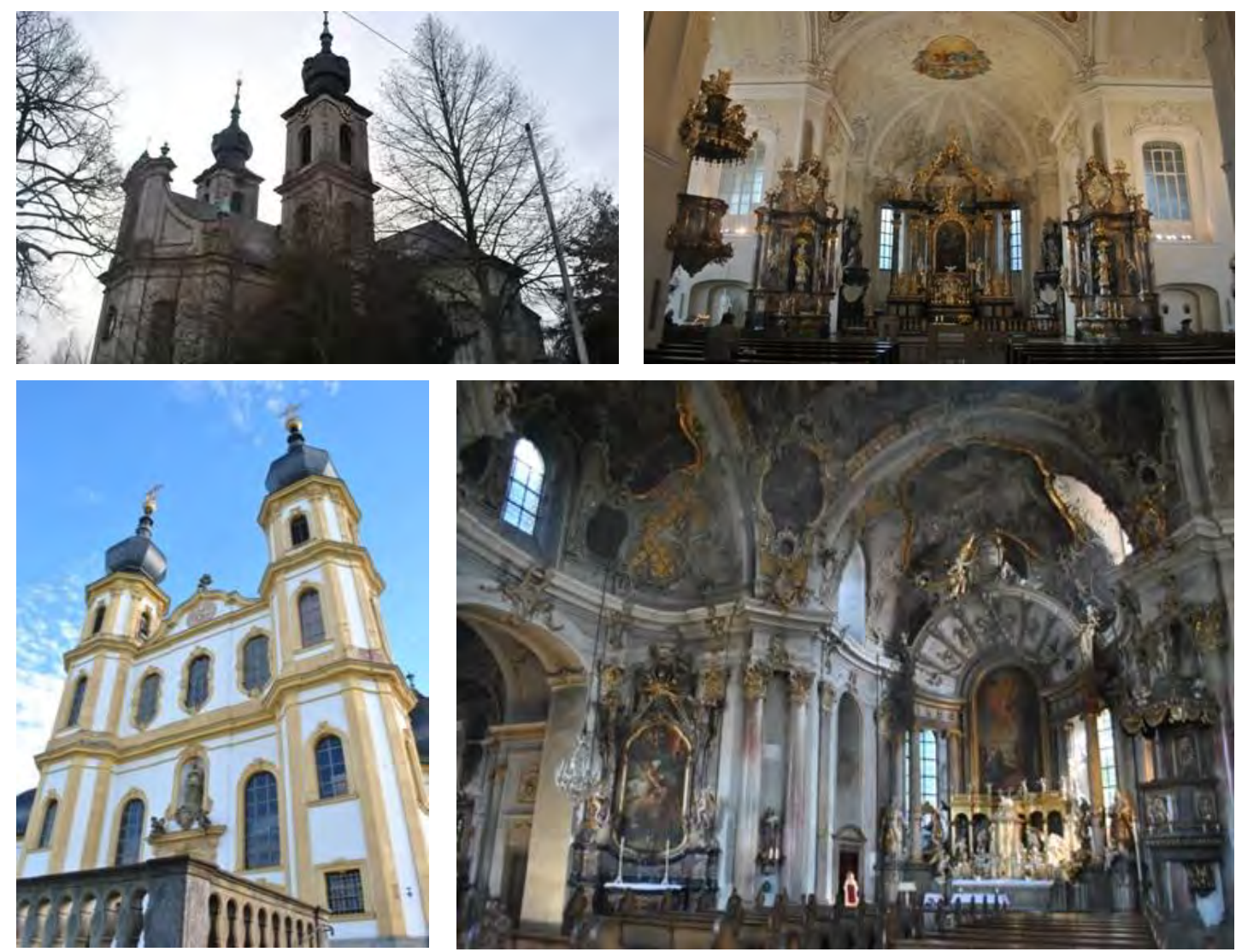

Fig. 9. Biserica St. Peter, Bruchsal (sus), biserica Käppele, Würzburg (jos). Arhitect Balthasar

Așa cum arată Bostenaru (2019a), în perioada imigrării numeroase biserici erau deja în construcție, și numeroase localități prezintă capdopere baroc. Geografia timpului (Hägerstrand, 1970) trebuie aplicată pentru a documenta legăturile dintre momentele imigrării și momentele clădirii. Activitatea de construcție s-ar putea să fi fost unul din motivele migrării, cum se arată în „Memorialul mănăstirii” al lui Jose Saramago pentru construcția din Mafra.

În Germania sunt câteva instituții în Baden-Württemberg care tratează șvabii dunăreni ca temă de cercetare. Mai precis și în UIm malul Dunării este denumit după ei, și prezintă o colecție de plăci de comemorare și un monument al emigrării. Șvabii sătmăreni au o plăcuță recentă din 8 septembrie 2018 care schițează și aceste principale monumente de arhitectură. Recent un proiect de cercetare de la Freiburg este dedicate renașterii arhitecturii rurale a șvabilor dunăreni, prin restaurări, și sperăm să urmeze mai multe, inclusiv privind arhitectura bisericilor.

\section{Referinţe}

Bara, J. (2016). Joseph Bittheuser (1755-1828), a Károlyi család uradalmi épitészének tevékenysége Szatmár megyében, in Orbán, J and Maros Megyei Múzeum (Eds.), Fundálók, pallérok, építészek Erdélyben, Erdélyi MúzeumEgyesület, Târgu Mureș, Cluj, pp. 53-90.

Bara, J. (2013). Patronajul artistic al familiei Károlyi în Carei și împrejurimi în secolul XVIII, Universitatea Babeș-Bolyai Facultatea de istorie și filosofie Școala doctorală "Istorie, civilizaţie, cultură" lucrare de doctorat. 
Bara, J. (2011). Adatok Franz Sebastian Rosenstingl nagykárolyi épülettervezöi tevékenységéhez In: Kovács Zsolt, Sarkadi Nagy Emese, Weisz Attila (Eds.) Liber Discipulorum: Tanulmányok Kovács András 65. Születésnapjára, Erdélyi Múzeum-Egyesület, Cluj, pp. 255-266.

Bostenaru Dan, M. (2019a). Baroque interiors in architecture in Swabian settlements, in Diaconescu, O. (Ed.) Architecture and Design - Design and Architecture / Interferences. 15FAI_International Scientific Session Proceedings, "Ion Mincu" Publishing House, Bucharest, pp. 60-72.

Bostenaru Dan, M. (2019b). Southern German Baroque and immigration to Sathmar (Romania), Journal of Urban and Landscape Planning 4 (1) (accepted).

Bostenaru Dan, M. (2018). Mapping Swabian migration in the 18th century to NW Romania (Sathmar county), Geopatterns 3 (2), 26-34, https://doi.org/10.5719/GeoP.3.2/3, http://www.geodinamic.ro/assets/geo-patterns/volumes/v3.2_26-34.pdf

Budapest Föváros Levéltára. Ybl Miklos Virtuális Archivum, http://ybl.bparchiv.hu/ accessed on 23.03.2019.

Hägerstrand, T. (1970). What about people in regional science? Papers of the Regional Science Association, 24, 7-21

Hostiuc, C. (2010). Barocul Românesc. Gesturi de Autoritate, Replici si Ecouri, NOI Media Print, Bucharest.

INFP: Bridging the gap between seismology and earthquake engineering: from the seismicity of Romania towards a refined implementation of seismic action en1998-1 in earthquake resistant design of buildings (BIGSEES project) http://infp.infp.ro/bigsees/default.htm

https://infp.maps.arcgis.com/apps/webappviewer/index.html?id=d653bf8267ac4ea2b10a53718097e eda accessed on 23.03.2019.

Oberschwäbische Barockstraße: Der offizielle Routenführer zur Kultur- und Ferienstrasse, Oberschwaben Tourismus, $2019 \quad$ https://www.oberschwabentourismus.de/uploads/tx_icbrochuresdownload/Oberschwaebische-Barockstrasse-2019.pdf accessed on 23.03.2019.

Oberschwäbische Barockstraße. La strada del barocco dell'alta Svevia, Oberschwaben Tourismus, 2019, https://www.oberschwaben-tourismus.de/uploads/tx_icbrochuresdownload/Strada-del-barocco.pdf accessed on 23.03.2019.

Fletcher, B. (1975). Sir Banister Fletcher's a History of Architecture, The Atholne Press, London.

Voitec-Dordea, M. (1994). Renaștere, Baroc și Rococo în arhitectura universală, Ed. Didactică și pedagogică, Bucharest.

Vonház, S. (1987). Die deutsche Ansiedlung in Komitat Sathmar, Laupheim.

Zsíros, T. (1983). The Érmellék earthquake of 1834, Acta Geodaet., Geophys., Hung., vol. 18, pp. 129Webografie

Planul de mobilitate urbană durabilă 2016-2030 - Regiunea București - Ilfov, http://tpbi.ro/files/proiect_pmud.pdf, accesat în 2019

Ioan, Augustin Locuind în vag, 2017, https://atelier.liternet.ro/articol/17703/Augustin-loan/Locuind-invag.html, accesat în 2019 


\title{
BAROQUE CHURCHES OF COUNTERREFORMATION AT THE SATHMAR SWABIANS 1
}

researcher PhD arch. Maria Bostenaru Dan

"Ion Mincu" University of Architecture and Urban Planning, Bucharest

Maria.Bostenaru-Dan@alumni.uni-karlsruhe.de

\begin{abstract}
After the church reformation introduced by Luther and Calvin, the catholic church launched a large programme of the so-called Counter-Reformation. One of the expressions of Counter-Reformation was building churches in Baroque style. Baroque churches, with their dynamic space and richly ornamented, were to transpose in architecture the theologic ideas of the church. The first baroque churches were built in Rome, as in case of other architecture styles.

Also during the time of Counter-Reformation there was a large process of coloniasisation in the Habsburg Monarchy, in order to increase the number of Catholic population. In this context in the Sathmar Area the Károlyi count from Carei brought Swabians (called later on Danube Swabians because they travelled on the Danube with the so-called Ulmer Schachtel) from the region Oberschwaben (Upper Suabia) in Germany. The region Oberschwaben is characterised by the presence of numerous monasteries to which the colonists belonged. During their emigration also here Baroque churches were built, by the Voralberger School, an Austrian architecture school, consisting of architect families. Also in the county of Sathmar under the mecenate of the Károlyi family Baroque churches were built, for example in Carei or the villages around, the later of Josef Bitthäuser. Two study trips were conducted, in Oberschwaben and Sathmar respectively, in order to investigate this architectural heritage conditioned by the historical context of Counter-Reformation. Maps were drawn which superpose the Baroque heritage, today a cultural route, with emigration areas. The churches in Sathmar differ of those in Oberschwaben being mor simple and closer to those in Banat, where the next colonists came, brought by emperor Maria Theresia. For this reason the relationship with those in Vienna was studied. An important difference is also that between church and monastery, in Oberschwaben numerous churches being monastery churches, with a Baroque library. In Oberschwaben monasteries were secularised during Napoleon time
\end{abstract}

Cuvinte cheie: migration, Baroque, church

\footnotetext{
${ }^{1}$ Acknowledgements: The presented research was done in frame of a project funded by the Hungarian Academy of Sciences through the DOMUS scholarship in the home country with the title "Swabian immigration in the 18th century in Sathmar county - exchange and challenges in church and rural architecture" https://sites.google.com/view/domusszulofoldiosztondij/home.
} 


\section{Introduction}

The purpose of this research was to compare Baroque church and vernacular architecture in Oberschwaben (Upper Suabia) in Germany, from where colonists started to come 1712 to the county of Sathmar in SW of today's Romania, around the headquarters of the Károlyi counts in Carei, who brought them, and those in Sathmar. It is inscribed in a broader topic regarding not only church architecture but also vernacular housing. The reason to look at was also to look at changes in a seismic area, since many of these churches were affected by the 1834 Érmellék earthquake.

One objective was to document how far emigration took place from places which were later fluorishing during Baroque time, when the emigration took place, with new constructions, or if the emigration was dictated by economic reason of the poorest. Another objective was to establish if with migration the migrants took with them patterns from the home country or adapted to the local conditions where they settled.

Shortly after the Sathmar peace the region around Carei was deserted by war and the count wanted to bring new work force, especially since the land was rich and bringing good harvest. The geography in the places of emigration in Oberschwaben was different - there there was a hilly region of orchards while in Carei is a plane of wheat and mais agriculture. However, the call was successful, and over a century numerous new villages were founded. Unlike in other regions of Romania from where the ethnic Germans emigrated back to Germany in the recent past, in Sathmar many localities feature larger parts still of the original population for which reason this research is interesting. There is little literature on the architecture in Sathmar. Julia Bara wrote a doctoral thesis (Bara, 2013) and numerous articles, but a monograph is still expected. Research on Swabians is done mainly from the point of view of anthropology (Roșu, 2015). Having relatives in the region this aspect could also be seen from inside. The situation is different in Oberschwaben. Some of the Baroque churches in Oberschwaben are relevant for global history of architecture (Voitec-Dordea, 1994) (Fletscher, 1975).

The main research method was the field study. Two field trips, one to Oberschwaben and one to Sathmar were performed. During these photographic material was first hand acquired. If being a cultural route the churches in Oberschwaben are well documented, those in Sathmar are difficultly accessible and not documented in their present state.

In order to prepare the field trips various maps of the region were drawn. For this the book by Stefan Vonház (1987) was a valuable help, since it provides the places of origin and of settlement of the migrants. This was supperposed to the cultural route and to the earthquake maps among others. Story maps of the visual results were also created. So far little archive research has been yet performed, and this is a limitation.

The main innovation is the documentation of a not yet sufficiently documented heritage and the innovative maps which permit seeing which are the most relevant places for the research.

\section{Methodology}

The research questions were approached with the method of mapping. Using the historical records gathered by Stefan Vonház (1987) the places the colonists came from were mapped and compared to those touched by building Baroque churches in frame of the mentioned Counter-Reformation. Upper Swabia displays a huge number of Baroque churches in its monasteries, which form a cultural route, the Upper Swabian Baroque Street (since 1966) 
(Oberschwäbische Barockstraße 2019a and b). In context of international literature on relevant Baroque works (Voitec-Dordea, 1994, Hostiuc, 2010, Fletcher, 1975) and considering the analysis of the maps with specific instruments, the main localities to be visited during the field trip were traced and the heritage documented. If Baroque churches in Upper Swabia are well documented, those in Sathmar are not. There is hardly any literature or web information on them, so a personal visit to the sites helped a lot the research. Personal communication was conducted to Júlia Bara who finished a doctorate on the topic (Bara, 2013). Previous research on architecture in Carei done during a postdoc fellowship was employed as well (Bostenaru, 2018). The Danube Swabian museum in UIm has been recently visited in frame of another stay. Travel to Vienna to present the results helped framing the research in the context of Austrian architecture, which might have influenced the research as much as the origin places.

Though church building was relevant as the church Counter-Reformation was the reason of immigration, research was done also at the level of vernacular architecture. This way I come close to the Kevin Lynch (1960) "image of the city" type of analysis, as we consider both landmarks and common buildings. If church reconstruction after damages was related to the 1834 earthquake, so was damage to vernacular architecture that giving the magnitude as in the studies of Zsíros (1983). All maps are freely available from the webpage of the project (https://sites.google.com/view/domusszulofoldiosztondij/ ).

I also put forward the hypothesis according to which the strong church building activity in Germany at the end of the thirty year war might not have been popular among the peasants, after the considerations in the novel on the building of the convent of Mafra by Jose Saramago. In order to make an instrument to migration from Oberschwaben to Sathmar the researcher participated to an Urban Eye workshop in Bucharest working on a game on how can something physical be taken with in frame of migration.

\section{Results and discussion}

Both church and vernacular architecture are different in the origin and the colonisation places. The church interiors (about which I wrote in Bostenaru 2019a) are rather richly painted in the origin places, which is not the case in Sathmar.

Fig. 1 and Table 1 summarise the effects of the earthquake.

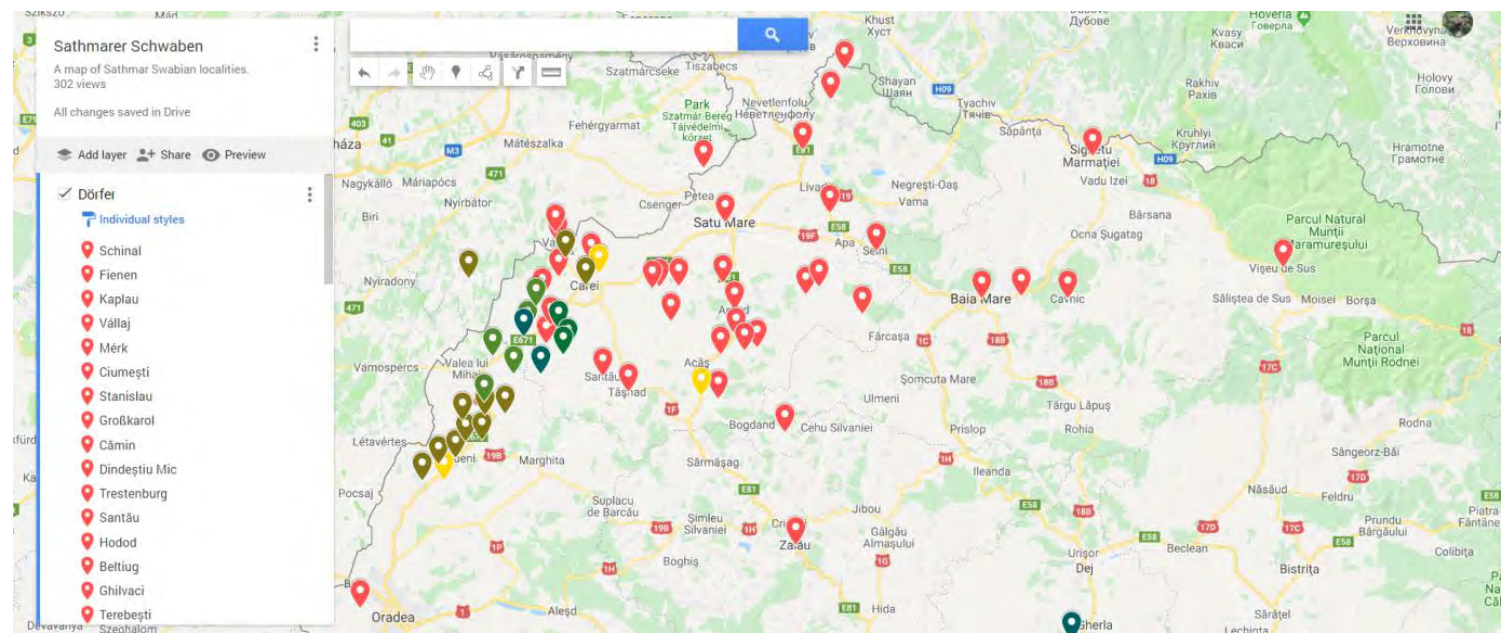

Fig. 1. Sathmar Swabians 'settlements supperposed to the intensities of the 1834 earthquake (after Zsíros, 1983).

Source: See full map here https://drive.google.com/open?id=1VojsRwIB1L94UsoziNgTxyQMVG-bzVuH\&usp=sharing See also INFP (2019). 
Table 1. Damages suffered by churches in the 1834 Érmellék earthquake

\begin{tabular}{|c|c|}
\hline Church & Effects of the 1834 earthquake \\
\hline $\begin{array}{l}\text { Reformed church } \\
\text { Ciumești }\end{array}$ & 1841 replacement of the ring (Fig. 2) \\
\hline $\begin{array}{l}\text { Roman-catholic } \\
\text { church Ciumești }\end{array}$ & $\begin{array}{l}\text { The first small church from } 1815 \text { suffered under the earthquake and a decision } \\
\text { of rebuild was taken. (Fig. 2) }\end{array}$ \\
\hline $\begin{array}{l}\text { St. Josef of } \\
\text { Kalazanc roman- } \\
\text { catholic church in } \\
\text { Carei }\end{array}$ & Collapse of the tower, reconstruction by Miklos Ybl with a lower tower. (Fig. 3) \\
\hline Church in Căpleni & Built during reconstruction after the earthquake(Fig. 4) \\
\hline $\begin{array}{l}\text { Reformed church } \\
\text { Carei }\end{array}$ & $\begin{array}{l}\text { The tower leaned, the roof of the tower and the bell fellt down. } 1836 \text { 26th of } \\
\text { June there was a fire damaging the roof. The tower was repaired 1877, and } \\
\text { foreseen with a new metal roof. (Bara, 2016) (Fig. 3) }\end{array}$ \\
\hline $\begin{array}{l}\text { Church in Moftinu } \\
\text { Mare }\end{array}$ & Not significantly damaged(Fig. 3) \\
\hline Church in Șandra & $\begin{array}{l}\text { During the repair works after the } 1834 \text { earthquake the roof becomes flat except } \\
\text { of the sacristy and under the orgel balcony. (Bara, 2016) - archive photo at } \\
\text { https://maps.hungaricana.hu/en/MOLTervtar/8215/ }\end{array}$ \\
\hline Church in Petrești & $\begin{array}{l}\text { Damaged, the tower falls on the main nave. As a consequence, the vaults are } \\
\text { exchanged for a flat roof in the interior, the original vaults remaining only in the } \\
\text { sacristy (Bara, 2016). } 1861 \text { the tower is rebuilt. (Fig. 6) }\end{array}$ \\
\hline Church in Foieni & $\begin{array}{l}\text { Damaged, the tower leans, and the tower roof is damaged, repaired in } 1838 \\
\text { (Bara, 2016). (Fig. 7) }\end{array}$ \\
\hline $\begin{array}{l}\text { Greek catholic } \\
\text { church Carei }\end{array}$ & Strongly damaged, but repaired. New reparations 1888. (Fig. 5) \\
\hline
\end{tabular}

The architects in Oberschwaben were Austrian, while for Banat, where the colonisation has been organised by Maria Theresia, there were typical plans from Vienna, although there are controverses in research on the influence of places of origin here as well. For Sathmar the architect of the roman catholic church St. Josef of Kalazanc and also of the initial plans for Foieni (Bara, 2016) came from Vienna (Bara, 2011) (Fig. 8) but the other, with more numerous buildings, from Würzburg (Bara, 2016), close to the Swabian architect who constructed Mafra in Portugal. The tower of St. Josef of Kalazanc was destroyed in the earthquake, but we can see towers of the architect at the Serviten chuch in Vienna, as the other tower in Vienna was also replaced (Fig. 8). Josef Bittheuser, the architect from Würzburg, should have seen built the works of Balthasar Neumann (Fig. 9) when raising up in the home city. This builds a link to South-German Baroque, including that in Oberschwaben, but also Bruchsal and Würzburg, from which a number of buildings are currently administrated by Staatliche Schlösser und Gärten Baden-Württemberg or by Bayrische Verwaltung der Staatlichen Schlösser, Gärten und Seen. 


\section{Conclusions}

In this work we mapped relevant aspects of the immigration of Swabians from Oberschwaben to Sathmar, initiated under count Sándor Károlyi in 1712. The immigration was a consequence of the Sathmar peace (1711) when the noble family was made of counts from barons. To the same time Maria Theresia supported bringing the colonists, who were Catholic, to the deserted areas after the war, in frame of the Counter-Reformation. Maria Theresia's colonists came later on. Consequently the family extended all across Hungary. Many of the castles of the family were built by Miklos Ybl who became the family architect after he contributed when young, to the reconstruction after the 1834 earthquake.

As Bostenaru (2019a) shows, during immigration numerous churches were already in building process, and numerous localities of origin display Baroque masterpieces. Time geography (Hägerstrand, 1970) has to be employed to document the connections between the moments of emigration and the moments of building. The construction activity might have belonged to the reasons of emigration, as shown in Jose Saramago's "Balthasar and Blimunda" for the construction in Mafra.

In Germany there is a number of institutions dealing with Danube Swabians in BadenWürttemberg. Precisely in Ulm the riverside of the Danube is named after them and displays a collection of remembrance plates and a monument of emigration. The Sathmar Swabians have a recent plate since the 8th of September 2018 displaying also these architectonic landmarks. Recently a research project in Freiburg is dedicated tot he renaissance of Danube Swabian rural architecture, through restorations, and we hope that many more will follow, also regarding church architecture.
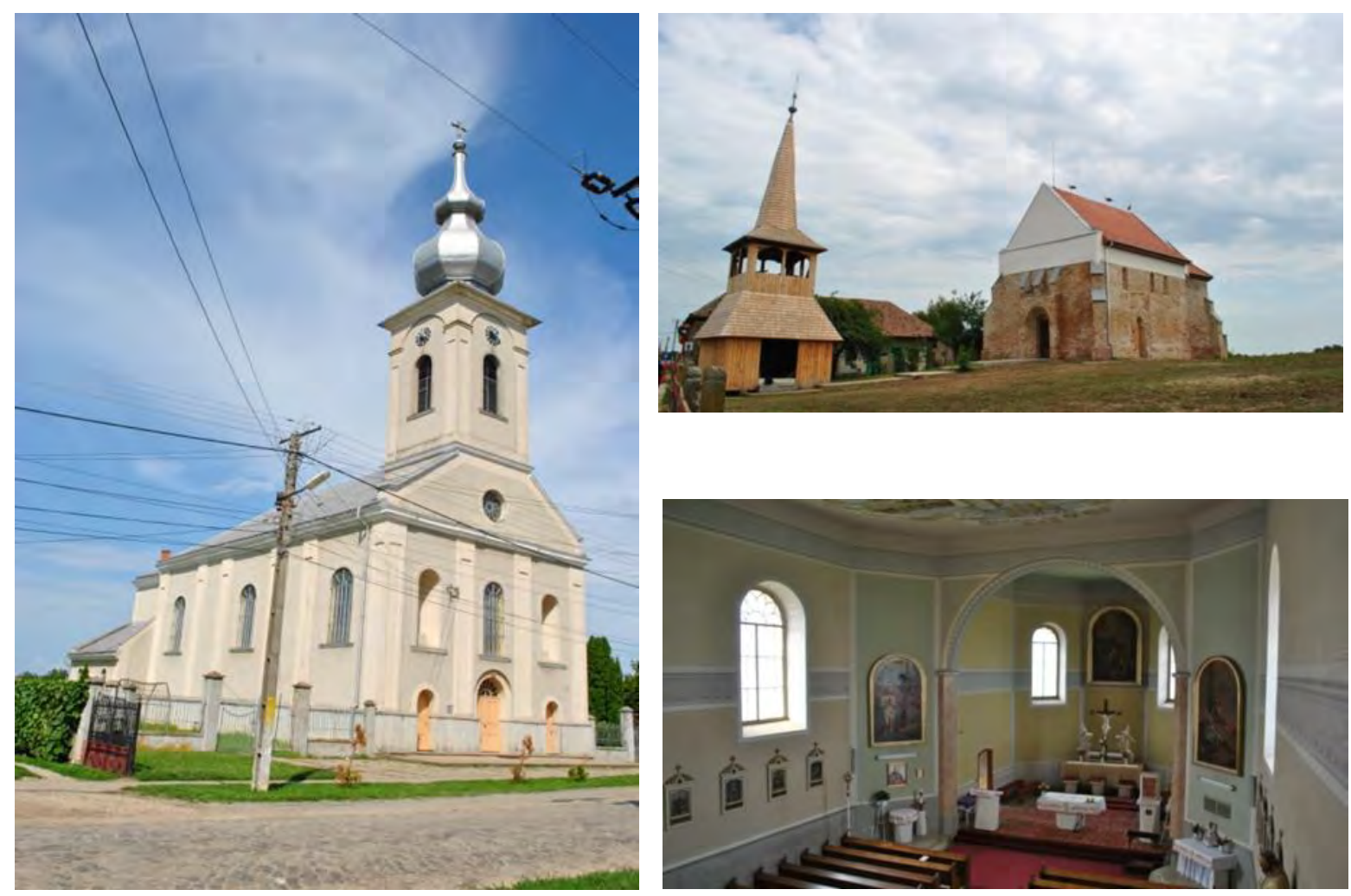

Fig. 2. The roman catholic church in Ciumești (1854-1856). Architect: Albin Tischler. Top right: the reformed church in Ciumești 

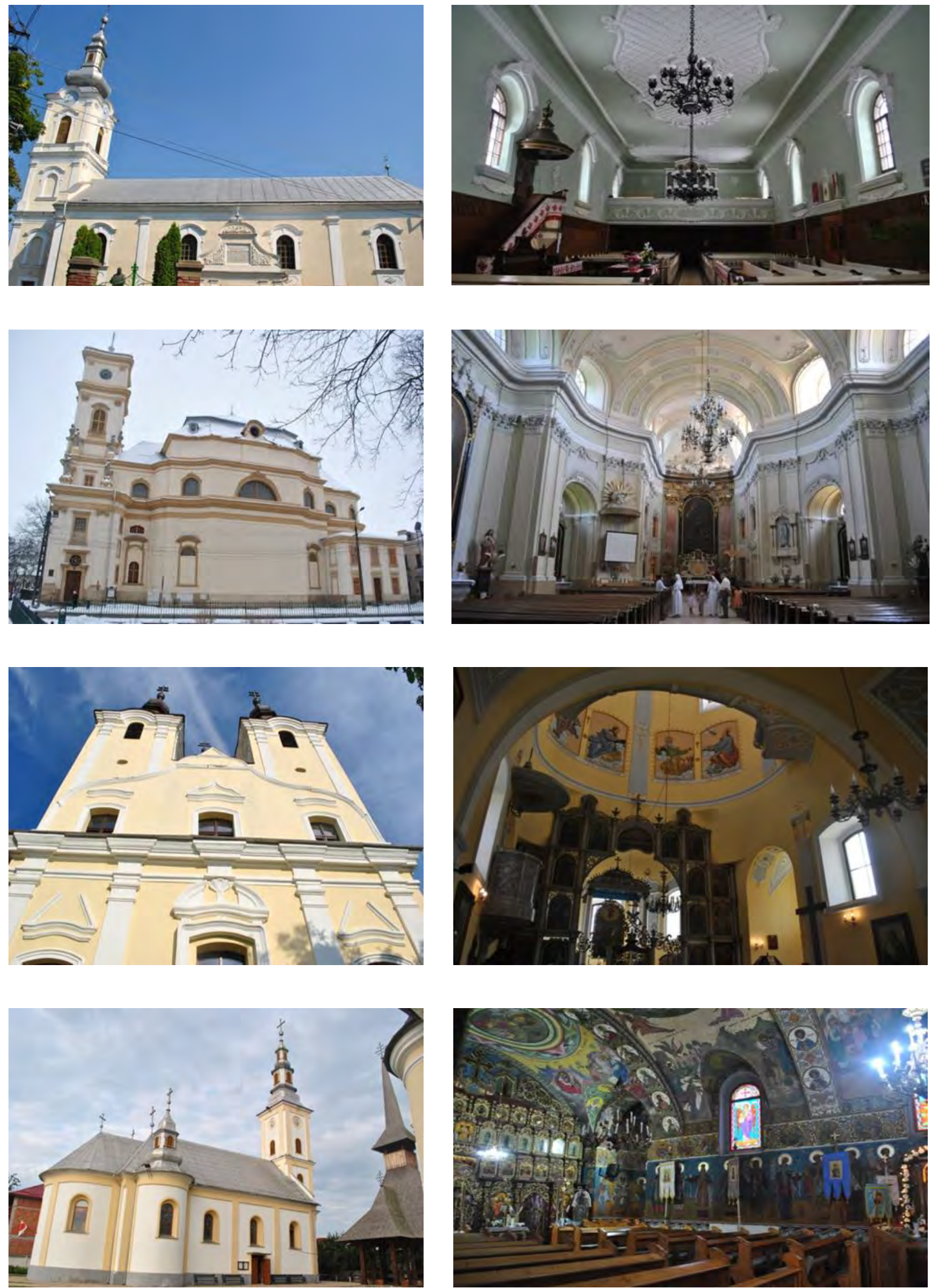

Fig. 3. The churches in Carei: reformed church, enlarged $1746-1752$ by architect Josef Bittheuser (top), roman catholic church St. Josef of Kalazanc, architect Franz Sebastian Rosenstingl (1769-1779) (middle up), Greek catholic (1737-1739) (middle down) and orthodox church (1752-) (bottom) 

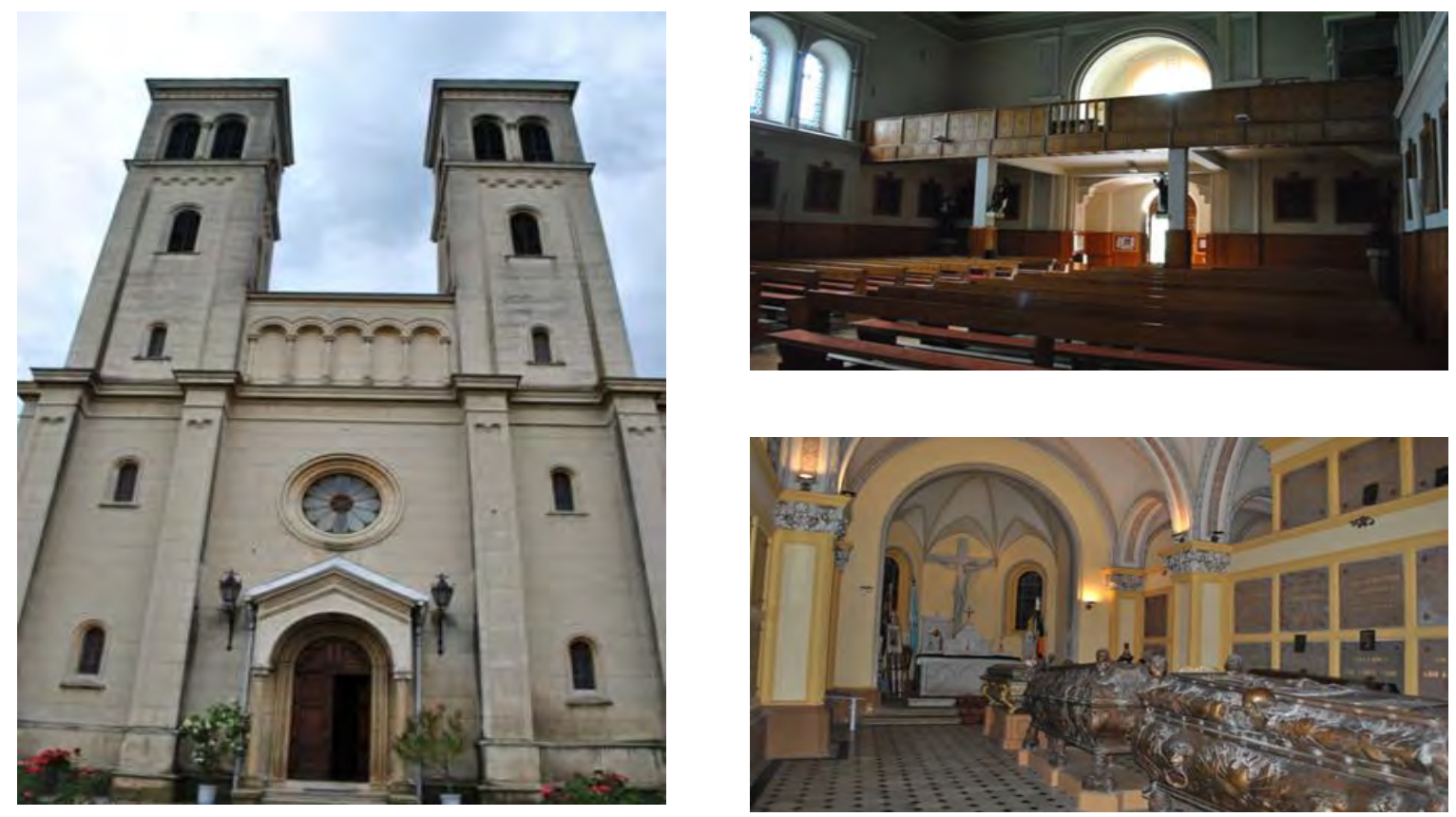

Fig. 4. The church in Căpleni (1842-1848), architect Miklos Ybl
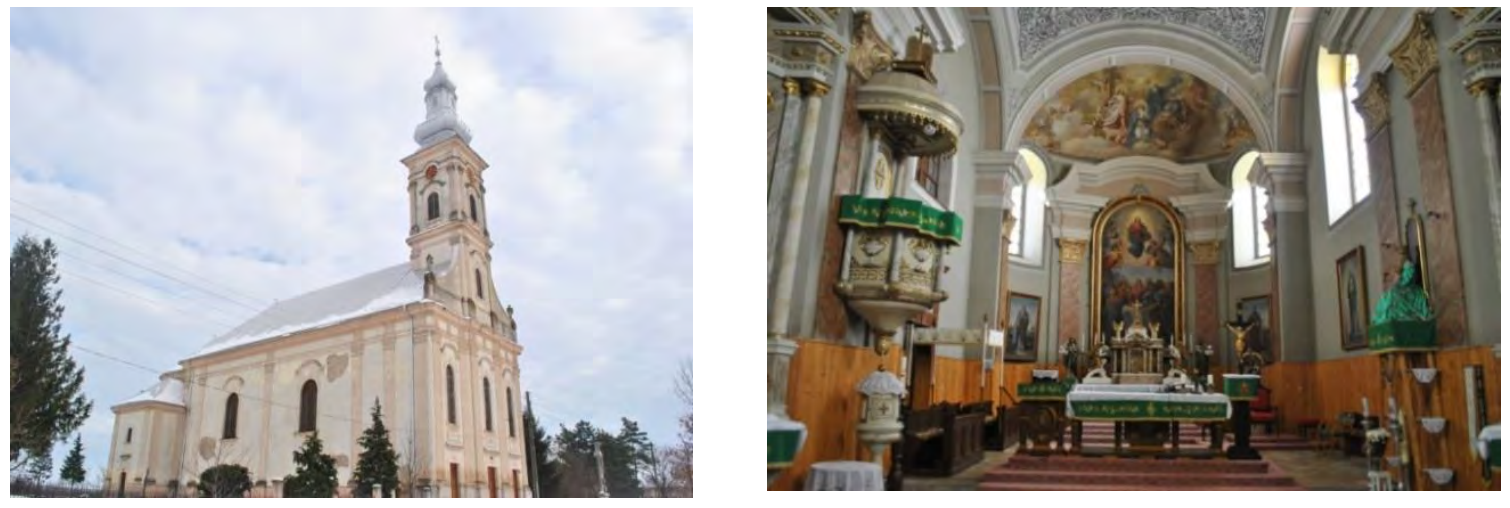

Fig. 5. The church in Moftinu Mare (1793-1797), architect Josef Bittheuser
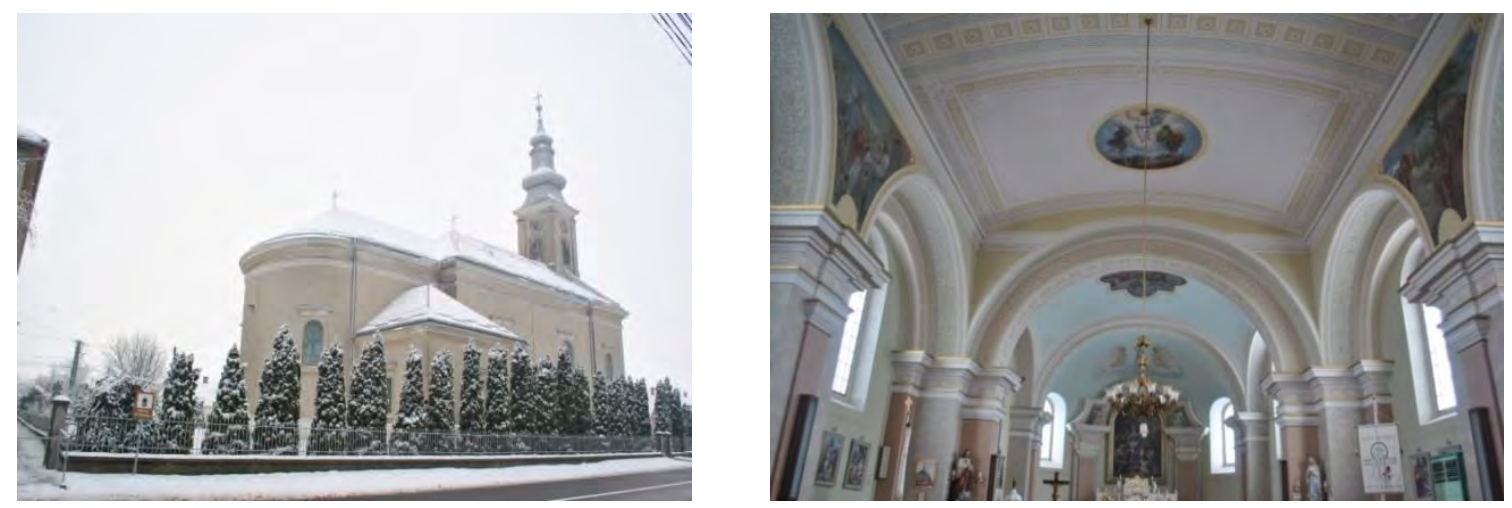

Fig. 6. The church in Petrești (1784-1786), architect Josef Bittheuser 

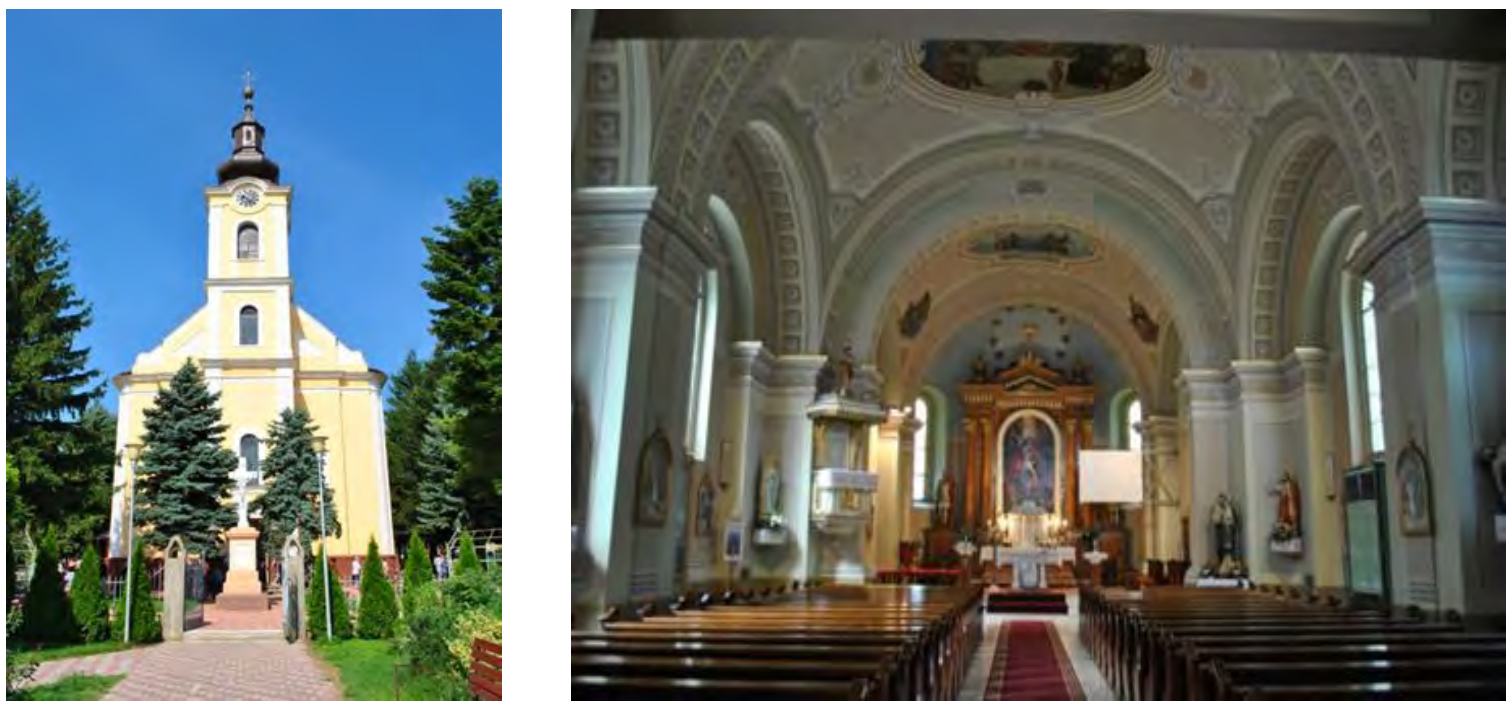

Fig. 7. The church in Foieni (1783-1785), architect Josef Bittheuser
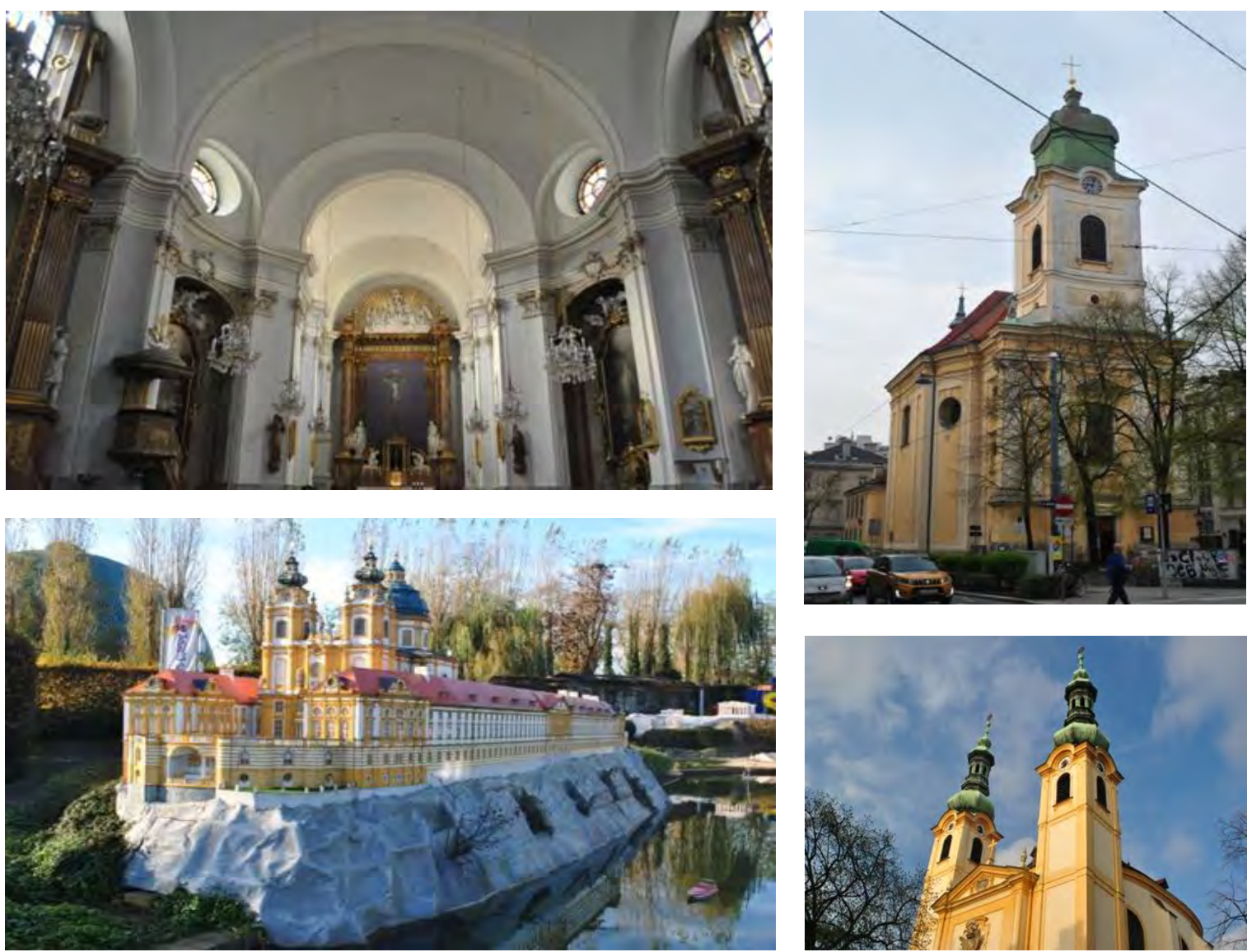

Fig. 8. The church in Gumpersdorf (top) and the Serviten church (bottom left), Vienna, architect Franz Sebastian Rosenstigl. Model of the monastery in Melk at Minieurope Brussels (bottom right), where the architect worked. 

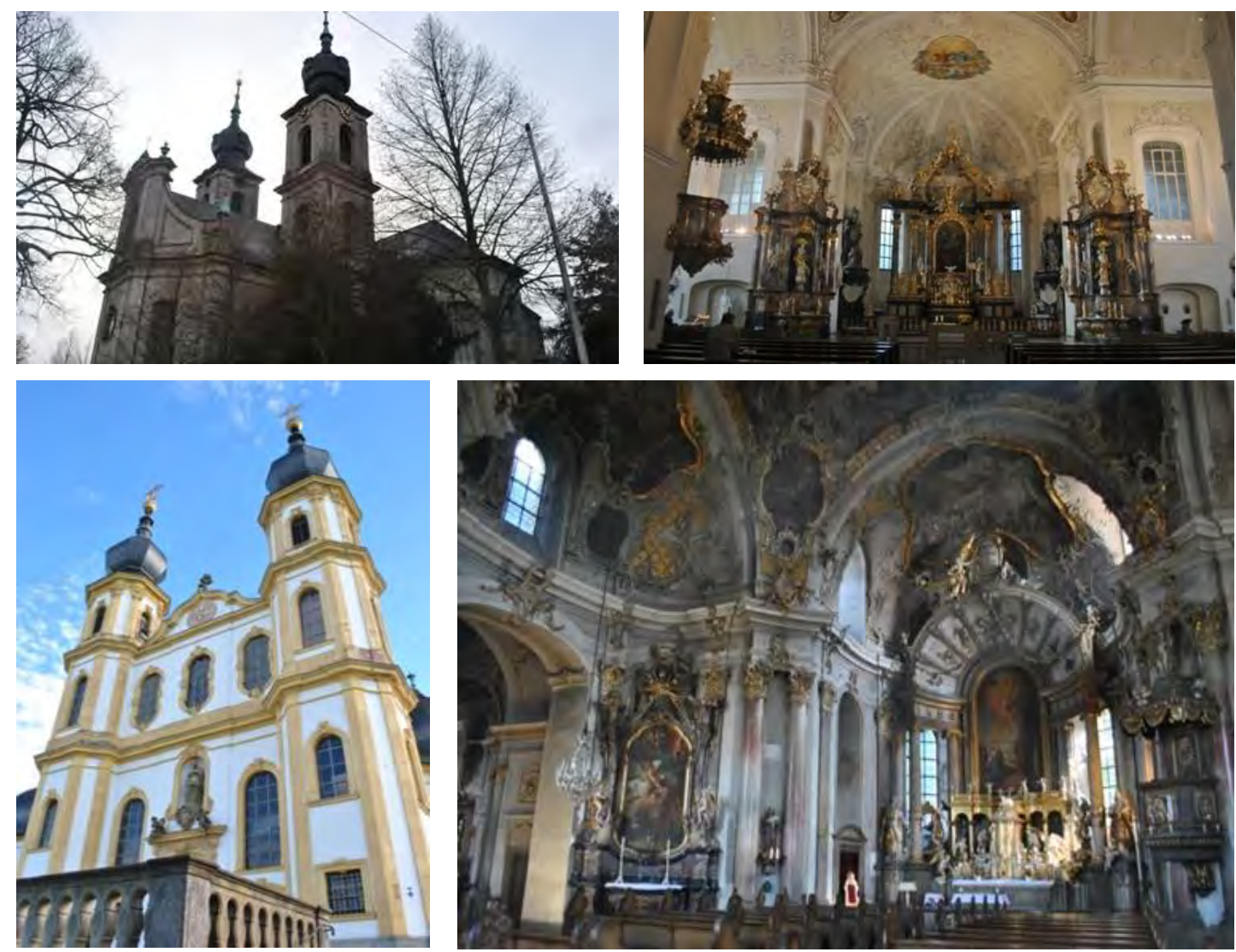

Fig. 9. St. Peter church, Bruchsal (top), Käppele church, Würzburg (bottom). Architect Balthasar Neumann Neumann.

\section{References}

Bara, J. (2016). Joseph Bittheuser (1755-1828), a Károlyi család uradalmi épitészének tevékenysége Szatmár megyében, in Orbán, J and Maros Megyei Múzeum (Eds.), Fundálók, pallérok, építészek Erdélyben, Erdélyi MúzeumEgyesület, Târgu Mureș, Cluj, pp. 53-90.

Bara, J. (2013). Patronajul artistic al familiei Károlyi în Carei și împrejurimi în secolul XVIII, Universitatea Babeș-Bolyai Facultatea de istorie și filosofie Școala doctorală "Istorie, civilizaţie, cultură" lucrare de doctorat.

Bara, J. (2011). Adatok Franz Sebastian Rosenstingl nagykárolyi épülettervezői tevékenységéhez In: Kovács Zsolt, Sarkadi Nagy Emese, Weisz Attila (Eds.) Liber Discipulorum: Tanulmányok Kovács András 65. Születésnapjára, Erdélyi Múzeum-Egyesület, Cluj, pp. 255-266.

Bostenaru Dan, M. (2019a). Baroque interiors in architecture in Swabian settlements, in Diaconescu, O. (Ed.) Architecture and Design - Design and Architecture / Interferences. 15FAI_International Scientific Session Proceedings, "Ion Mincu" Publishing House, Bucharest, pp. 60-72.

Bostenaru Dan, M. (2019b). Southern German Baroque and immigration to Sathmar (Romania), Journal of Urban and Landscape Planning 4 (1) (accepted).

Bostenaru Dan, M. (2018). Mapping Swabian migration in the 18th century to NW Romania (Sathmar county), Geopatterns 3 (2), 26-34, https://doi.org/10.5719/GeoP.3.2/3, http://www.geodinamic.ro/assets/geo-patterns/volumes/v3.2_26-34.pdf 
Budapest Föváros Levéltára. Ybl Miklos Virtuális Archivum, http://ybl.bparchiv.hu/ accessed on 23.03.2019.

Hägerstrand, T. (1970). What about people in regional science? Papers of the Regional Science Association, 24, 7-21

Hostiuc, C. (2010). Barocul Românesc. Gesturi de Autoritate, Replici si Ecouri, NOI Media Print, Bucharest.

INFP: Bridging the gap between seismology and earthquake engineering: from the seismicity of Romania towards a refined implementation of seismic action en1998-1 in earthquake resistant design of buildings (BIGSEES project) http://infp.infp.ro/bigsees/default.htm

https://infp.maps.arcgis.com/apps/webappviewer/index.html?id=d653bf8267ac4ea2b10a53718097e eda accessed on 23.03.2019.

Oberschwäbische Barockstraße: Der offizielle Routenführer zur Kultur- und Ferienstrasse, Oberschwaben Tourismus, $2019 \quad$ https://www.oberschwabentourismus.de/uploads/tx_icbrochuresdownload/Oberschwaebische-Barockstrasse-2019.pdf accessed on 23.03.2019.

Oberschwäbische Barockstraße. La strada del barocco dell'alta Svevia, Oberschwaben Tourismus, 2019, https://www.oberschwaben-tourismus.de/uploads/tx_icbrochuresdownload/Strada-del-barocco.pdf accessed on 23.03.2019.

Fletcher, B. (1975). Sir Banister Fletcher's a History of Architecture, The Atholne Press, London.

Voitec-Dordea, M. (1994). Renaștere, Baroc și Rococo în arhitectura universală, Ed. Didactică și pedagogică, Bucharest.

Vonház, S. (1987). Die deutsche Ansiedlung in Komitat Sathmar, Laupheim.

Zsíros, T. (1983). The Érmellék earthquake of 1834, Acta Geodaet., Geophys., Hung., vol. 18, pp. 129134. 